\title{
A CLEAR WATER SCOUR AROUND A CIRCULAR BRIDGE PIER UNDER STEADY FLOW FOR DIFFERENT OPENING RATIOS
}

\author{
A. R. Deshmukh ${ }^{1}$, R. V. Raikar ${ }^{2}$ \\ ${ }^{1}$ Department of Civil Engineering, Rajarshi Shahu College of Engg, Tathwade, Pune 411033 (Maharashtra) \\ ${ }^{2}$ Professor, Department of Civil Engineering,K.L.E.S. College of Engineering, Udaumbaug, Belgaum (Karnataka)
}

\begin{abstract}
The loose non cohesive material through which a river flows is generally called sediment. Local scour at piers and abutments is the main reason for the collapse of bridges founded in alluvial sediments. Clear water scour refers to the situation where no sediment is supplied by the approaching flow in the zone of scour. Many investigators have studied various aspects of scour. However, the study on scour under steady condition for same discharge with same depth of flow for different pier diameters is limited. In present study laboratory experiment was conducted on different pier sizes of circular piers by keeping discharge constant under clear water scour condition. It is found that Non dimensional scour depth gradient is different up to opening ratio 0.8 having less slope and its slope is steep above 0.8 opening ratio.
\end{abstract}

Keywords: -clear water scour; Froude's number; sediment; equilibrium scour.

\section{INTRODUCTION}

The loose non-cohesive material through which a river flows is generally called sediment. The change in flow characteristics of the river during floods and the flow modification at structures such as piers, abutments, etc. induces the erosive force on the river bed. The lowering of stream bed elevation of river, which takes place in the vicinity of structure such as bridge pier[2], abutment or guide bunds etc. is called local scour. The horse shoe vortex around a bridge pier and down flow contributes significantly to the scour. Fig. 1 shows the flow structure at a bridge pier [4].

However, the study on scour under steady condition for same discharge with same depth of flow for different pier diameters is limited. The problem of local scour around bridge piers and abutments placed in an alluvial channel is of great importance to hydraulic engineers for its safe and economic design. The scour occurs due to change in flow pattern, due to increase in shear stress, three dimensional flow separations and its interaction with transport of sediment and changing mobile boundary. Depending on the supply of sediment by the approaching flow, the scour is classified as: clear water scour and live bed scour. Clear water scour refers to the situation where no sediment is supplied by approaching flow in zone of scour while scouring is in progress. On the other hand, live bed scour occurs when there is a supply of sediment in to the scour hole while sediment is being removed from scour hole.

Shen et al. [8] distinguished between 1) clear water scour: when upstream flow does not transport sediment and 2) sediment transporting (live bed) scour when upstream flow transport sediment. Clear water scour is asymptotic in nature and it takes much longer time to reach, while sediment transporting scour is of dynamic nature and it is reached much more rapidly. The depth of scour in live bed conditions is usually $10 \%$ smaller than that of clear water scour, other conditions remaining same.

Many investigators have studied various aspects of scour such as maximum depth of scour, effect of sediment, size and gradation, effect of pier and abutment shape and size, time dependent scour, mechanism of scour hole and development [1]. However, the study on scour under unsteady condition is limited.

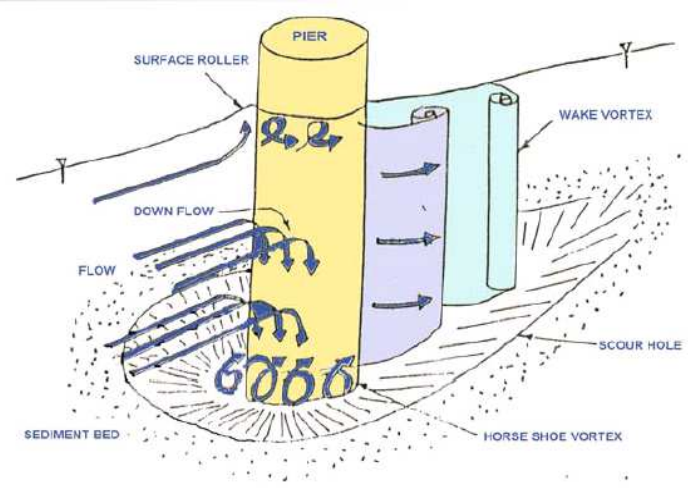

Fig. 1: Flow structure around circular bridge pier [4] 
The accurate estimation of maximum depth of scour at bridge pier in an alluvial stream is required for safe and economical design of bridge pier because underestimation may lead to bridge failure and overestimation may lead to unnecessary construction cost[ 3]. The most common cause of bridge failure is scouring at bridge piers during floods.

The flow field around pier is coupled with a complex three dimensional separation of the approaching flow on the upstream and periodical vortex shedding on the downstream of the pier. The complexity increases with the development of scour hole. The main characteristic features of the flow around a pier on a flat surface are relatively large secondary flow and skewed velocity distribution caused by the pressure gradient normal to the approaching flow direction [2].

\section{EXPERIMENTAL SET UP}

Experiments were conducted in a rectangular tilting flume in Fluid Mechanics laboratory at Rajarshi Shahu College of Engineering, Pune having $0.30 \mathrm{~m}$ width, 8-10 m length and $0.30 \mathrm{~m}$ depth having maximum discharge up to $10 \mathrm{lps}$. For discharge measurement orifice meter is used which is fitted on delivery pipe of centrifugal pump. Recirculation system is adopted. The flow rate is adjusted by controlling valve. The valve is slowly operated without disturbance to the bed surface until the desired depth is obtained. Required water depth is obtained by tail gate. The water surface is measured using point gauge which is sensitive to the variation of $0.1 \mathrm{~mm}$. The scour depth is measured through periscope at different time interval from scale attached inside to pier.

Existing bed level is elevated by $10 \mathrm{~cm}$ with acrylic sheets on upstream, which is shown in detail in Fig. 2 and mobile bed zone of $185 \mathrm{~cm}$ long $30 \mathrm{~cm}$ wide, and $10 \mathrm{cmdeep}$ is prepared at distance of $2.25 \mathrm{~m}$ downstream of the flume beginning and is filled with sediment of a median particle size $1.10 \mathrm{~mm}$. To enter water in channel without turbulence, false bed was shaped tapered at entrance. Before the start of each run, experiments were conducted to maintain clear water scour for given sediment size without pier.

Cylindrical piers of sizes 25,40, 60, 75 and $90 \mathrm{~mm}$ were used to decide maximum size of pier which would determine only a local scour without a contraction effect. Piers were placed vertically at center of sediment zone. The sediment zone is leveled before starting tests. The control valve was adjusted in such a manner that clear water condition would get developed without causing any disturbance to the bed material.

For each pier, experiments were conducted by keeping all experimental parameters same i.e. flow depth, bed slope and sediment. The scour depth was measured at different time intervals from a scale attached to the pier. Each run was of 3 hours. Details of experiments are summarized in Table 1.

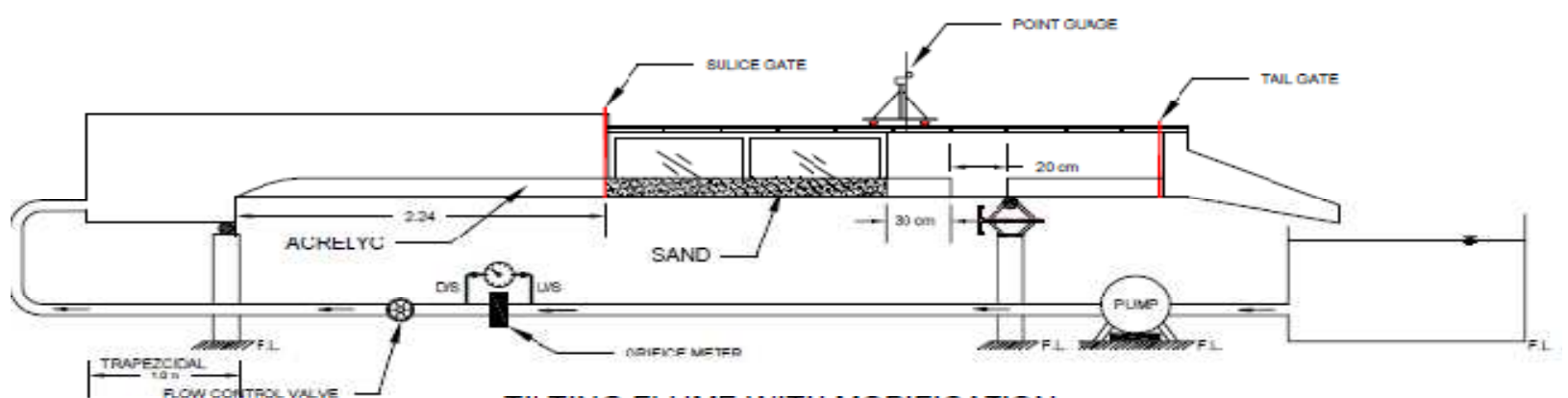

TILTING FLUME WITH MODIFICATION

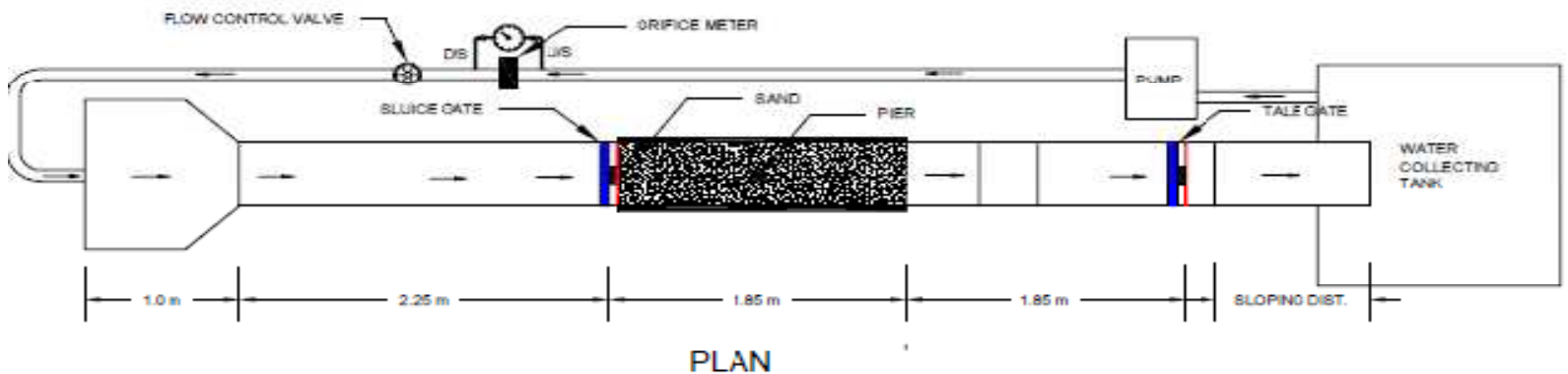

Fig.2: Experimental set up 


\section{RESULTS AND DISCUSSIONS}

Calculation for a clear water scour condition,

$\mathrm{u}^{*}=0.02815 \mathrm{~m} / \mathrm{s}$

From Sheilds curve

Particle parameter, $\mathrm{D}_{*}=\mathrm{D}_{50}\left[\frac{(\mathrm{s}-1) \mathrm{g}}{v^{2}}\right]^{1 / 3}$

$\mathrm{D}_{*}=26.518$

Table 1: Observation for depth of scour for different piers (Depth of flow $=10 \mathrm{~cm}$ )
For $20<\mathrm{D} * \leq 150$

$$
\text { Өcr }=0.013\left(D^{*}\right) 0.29
$$

Critical mobility parameter $\Theta_{\mathrm{cr}}={\frac{(\mathrm{u} * \mathrm{cr})}{(\mathrm{s}-1) \mathrm{gD}_{50}}}^{2}$

$$
\begin{gathered}
\Theta_{\mathrm{cr}}=0.03364 \\
\mathrm{u}_{*_{\mathrm{c}}}=0.0367 \mathrm{~m} / \mathrm{s}
\end{gathered}
$$

\begin{tabular}{|c|c|c|c|c|c|c|c|c|c|}
\hline \multicolumn{10}{|c|}{ Non-dimensional scour depth Pier diameter } \\
\hline \multicolumn{2}{|c|}{$25 \mathrm{~mm}$} & \multicolumn{2}{|c|}{$40 \mathrm{~mm}$} & \multicolumn{2}{|c|}{$60 \mathrm{~mm}$} & \multicolumn{2}{|c|}{$75 \mathrm{~mm}$} & \multicolumn{2}{|c|}{$90 \mathrm{~mm}$} \\
\hline t/te & $\mathrm{ds} / \mathrm{b}$ & $\mathrm{t} / \mathrm{te}$ & $\mathrm{ds} / \mathrm{b}$ & t/te & $\mathrm{ds} / \mathrm{b}$ & t/te & $\mathrm{ds} / \mathrm{b}$ & $\mathrm{t} / \mathrm{te}$ & $\mathrm{ds} / \mathrm{b}$ \\
\hline 0 & 0 & 0 & 0 & 0 & 0 & 0 & 0 & 0 & 0 \\
\hline 0.055 & 0.6 & 0.055 & 0.475 & 0.055 & 0.433 & 0.055 & 0.40 & 0.055 & 0.355 \\
\hline 0.11 & 0.64 & 0.11 & 0.50 & 0.11 & 0.483 & 0.11 & 0.453 & 0.11 & 0.422 \\
\hline 0.166 & 0.68 & 0.166 & 0.55 & 0.166 & 0.50 & 0.166 & 0.466 & 0.166 & 0.455 \\
\hline 0.22 & 0.68 & 0.22 & 0.60 & 0.22 & 0.533 & 0.22 & 0.480 & 0.22 & 0.477 \\
\hline 0.27 & 0.68 & 0.27 & 0.625 & 0.27 & 0.55 & 0.27 & 0.506 & 0.27 & 0.477 \\
\hline 0.33 & 0.72 & 0.33 & 0.625 & 0.33 & 0.566 & 0.33 & 0.506 & 0.33 & 0.477 \\
\hline 0.38 & 0.76 & 0.38 & 0.65 & 0.38 & 0.583 & 0.38 & 0.52 & 0.38 & 0.477 \\
\hline 0.44 & 0.76 & 0.44 & 0.65 & 0.44 & 0.583 & 0.44 & 0.52 & 0.44 & 0.477 \\
\hline 0.5 & 0.76 & 0.5 & 0.675 & 0.5 & 0.583 & 0.5 & 0.52 & 0.5 & 0.488 \\
\hline 0.55 & 0.76 & 0.55 & 0.675 & 0.55 & 0.583 & 0.55 & 0.52 & 0.55 & 0.488 \\
\hline 0.611 & 0.76 & 0.611 & 0.675 & 0.611 & 0.60 & 0.611 & 0.533 & 0.611 & 0.488 \\
\hline 0.66 & 0.76 & 0.66 & 0.675 & 0.66 & 0.60 & 0.66 & 0.533 & 0.66 & 0.488 \\
\hline 0.72 & 0.80 & 0.72 & 0.675 & 0.72 & 0.60 & 0.72 & 0.533 & 0.72 & $0 . .50$ \\
\hline 0.77 & 0.80 & 0.77 & 0.70 & 0.77 & 0.60 & 0.77 & 0.533 & 0.77 & 0.50 \\
\hline 0.83 & 0.80 & 0.83 & 0.70 & 0.83 & 0.60 & 0.83 & 0.533 & 0.83 & 0.50 \\
\hline 0.88 & 0.80 & 0.88 & 0.70 & 0.88 & 0.60 & 0.88 & 0.533 & 0.88 & 0.50 \\
\hline 0.94 & 0.80 & 0.94 & 0.70 & 0.94 & 0.60 & 0.94 & 0.533 & 0.94 & 0.50 \\
\hline 1 & 0.80 & 1 & 0.70 & 1 & 0.60 & 1 & 0.533 & 1 & 0.50 \\
\hline
\end{tabular}

$\mathrm{u}_{*} / \mathrm{u}_{*_{\mathrm{c}}}=0.76<1$ clear water condition $\quad[9]$

$\mathrm{t} / \mathrm{te}=$ Non dimensional parameter of time; $\mathrm{ds} / \mathrm{b}=$ Non dimensional scour depth at that time 


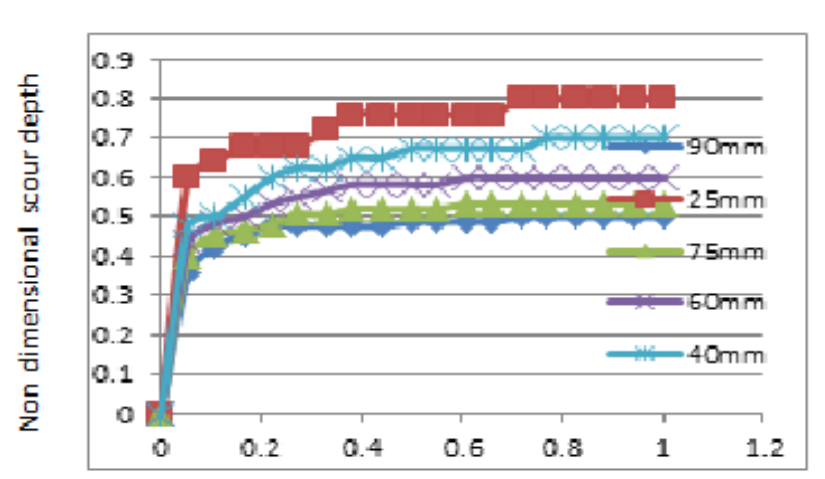

Non dimensional time

Fig.3:Non Dimensional Scour Depth Vs time for different piers

Table 2: Observation of opening ratio and maximum scour depth.

\begin{tabular}{|c|c|c|c|}
\hline $\begin{array}{c}\text { Diameter of } \\
\text { pier }(\mathrm{mm})\end{array}$ & $\begin{array}{c}\text { Opening } \\
\text { ratio }(\alpha)\end{array}$ & $\begin{array}{l}\text { Depth of } \\
\text { scour S (cm) }\end{array}$ & $\begin{array}{l}\text { Dimension } \\
\text { less scour } \\
\text { depth } \\
(\mathrm{ds} / \mathrm{b})\end{array}$ \\
\hline 25 & 0.9166 & 2.0 & 0.80 \\
\hline 40 & 0.8666 & 2.8 & 0.70 \\
\hline 60 & 0.80 & 3.6 & 0.60 \\
\hline 75 & 0.75 & 4.0 & 0.53 \\
\hline 90 & 0.70 & 4.5 & 0.50 \\
\hline
\end{tabular}

\section{Where}

Opening ratio $(\alpha)=(B-b) / B$.

$\mathrm{B}$ is width of channel.

$\mathrm{b}$ is a pier diameter / width of pier normal to the direction of flow

ds

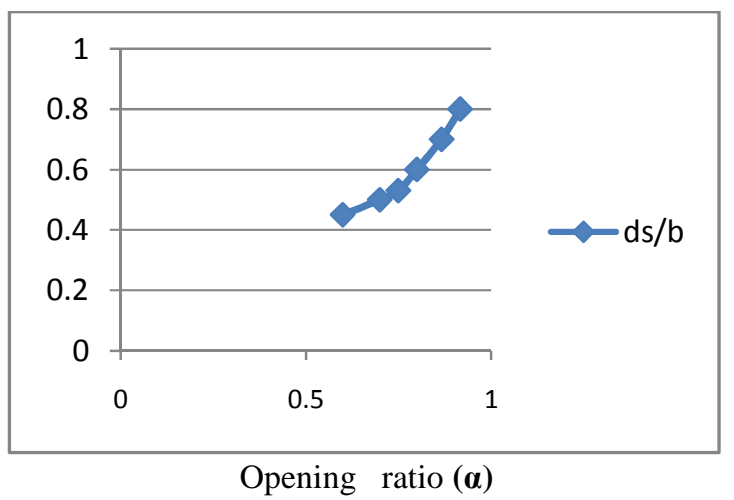

Fig.4:Effect of opening ratio( $\alpha$ ) non-dimensional maximum scour depth(ds/b)

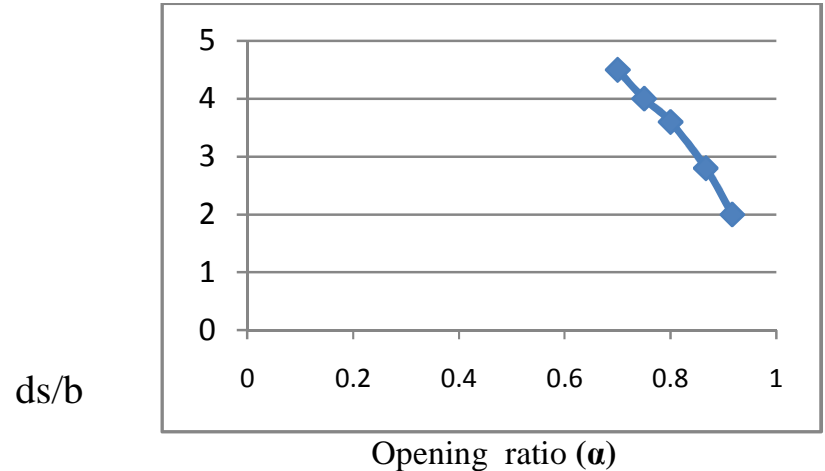

Fig. 5: Maximum scour depth vs opening ratio

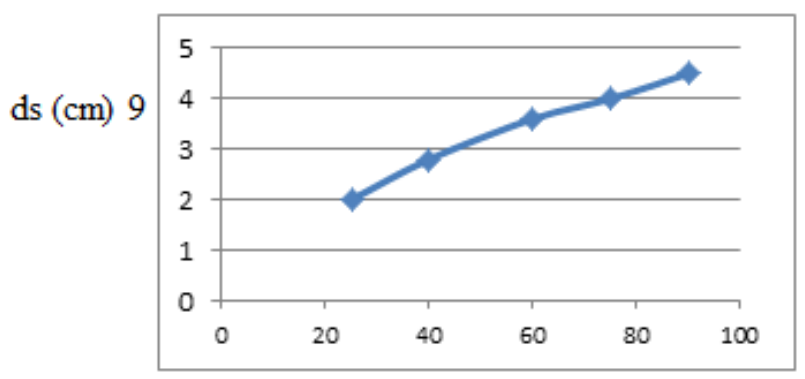

Pier dianatar (b)

Fig.6:Variation of scour depth with pier diameter

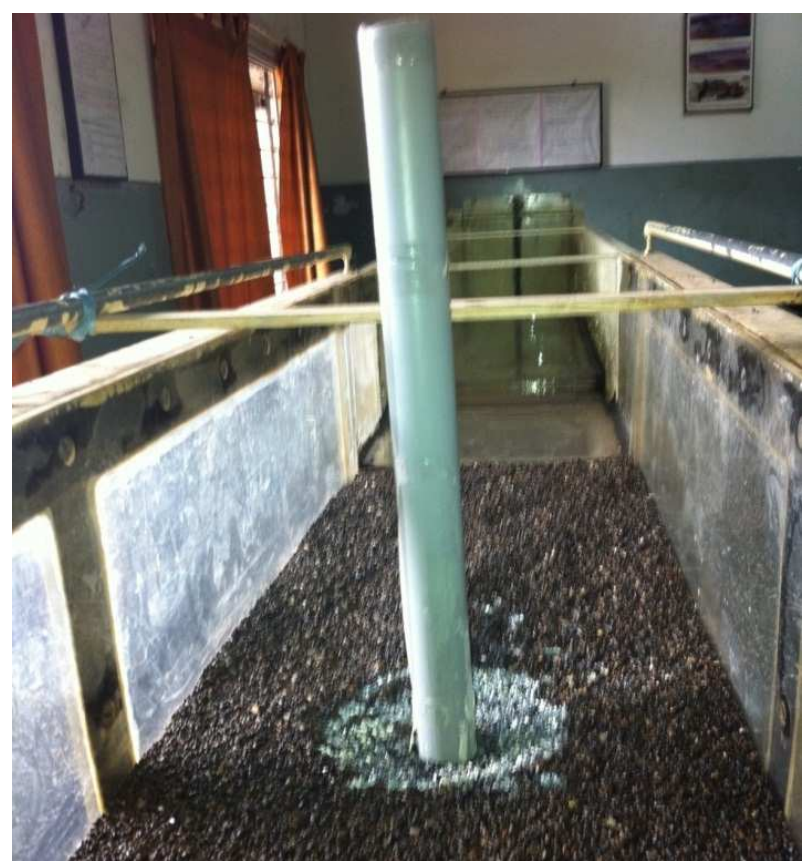

Fig.7: Pattern of scour observed around 25mm diameter pier 


\section{CONCLUSIONS}

It can be concluded that, Scour depth goes on increasing with time up to certain limit and it attains a constant depth of scour which is considered as equilibrium scour depth. The scour depth increases with an increase in pier diameter by keeping all parameters i.e. flow characteristics and sediment characteristics same. Maximum depth is observed on the upstream side of pier. The scour pattern observed around 25 $\mathrm{mm}$ pier diameter is shown in Fig. 7.Lateral extent is observed to be more on the upstream side of the pier. Non dimensional scour depth gradient is different up to opening ratio 0.8 having less slope and its slope is steep above 0.8 opening ratio.

\section{REFERENCES}

[1].Dargahi B. (1982) Local Scour at Bridge Piers-A Review of Theory and Practice. Bulletin no.TRITA-UBI-114, Stockholm (Sweden)

[2].Dey S. (1999) Local Scour at pier (Part-I)-A Review of Development of Research. International Journal of Sediment Research.Vol.12, No.2, pp 23-44.

[3].Garde R.J. and Kothyari U.C. (1995) State Of Art Report on Scour around Bridge Piers.IIBE, Mumbai.

[4]. R. J. and RangaRaju, K. G .(2000). "Mechanics of Sediment Transportation and Alluvial Streams Problems." The New Age Publisher, New Delhi.

[5].Melville, B. W. and Chiew, Y. M. (1999). "Time Scale for Local Scour at Bridge Piers." J. Hydraul. Engg, ASCE. Vol. $125(1), 59-65$.

[6].Shen H. W.,Schneider V R and Karki, S.( 1969).”Local Scour Around Bridge Piers." J. Hydraul. Engg,ASCE. Vol. 95 (6), 1919-1940

[7].Yanmaz, A. M. and Altinblilek, H. D. (1991). "Study of Time-Dependent Local Scour Around Bridge Piers." J. Hydraul. Engg,ASCE. Vol. 117 (10), 1247-1268.

[8]. C van Rijn (1984)Sediment Transport ,Part I.BedLoadtransport .' J. Hydraul. Engg, ASCE. Vol. 110 (10), 1431-1456. 